\title{
RELEVYNCE
}

\section{Analisis Pengaruh Kualitas Pelayanan, Harga, Fasilitas Dan Customer Loyalty Terhadap Kepuasan Pasien Rawat Jalan Pada Rumah Sakit Medika Permata Hijau Jakarta}

\author{
Sri Mulyono \\ Institut Darul Qur'an
}

\begin{tabular}{|c|c|}
\hline $\begin{array}{l}\text { ARTICLE } \\
\text { INFORM }\end{array}$ & \\
\hline RELEVAN & \\
\hline Vol.2, No. 2, I & ber 2019 \\
\hline Page : $241-2$ & \\
\hline $\begin{array}{l}\text { ISSN (online) } \\
\text { ISSN (print) }\end{array}$ & $\begin{array}{l}: 2615-8590 \\
: 2615-6385\end{array}$ \\
\hline
\end{tabular}

Keywords :

Service Quality, Cost, Facility Customer Loyalty

\section{JEL classifications:}

G11, G33

\section{Contact Author :}

amulyonodpk@yahoo.com

\begin{abstract}
Medika Permata Hijau (RSMPH) Hospital is one of hospitals affiliated in KPJ Health Care (Bhd) managing 25 hospitals centered in Kuala Lumpur, Malaysia and two hospitals in Indonesia. This study has some objectives which are to analyze the service quality influence towards outpatients' satisfaction, the cost influence towards outpatients' satisfaction, the facility influence toward outpatients' satisfaction, customer loyalty influence towards outpatients' satisfaction. This study uses quantitative method with research object discussed in this study I outpatients of Medika Permata Hijau Jakarta Hospital. The participants of this study were conveniently selected by employing non probability sampling technique. The validity of the data were analyzed by using Pearson Correlation Test, and the reliabitity of the data were analyzed by using Cronbach's Alpha score in $X_{1}, X_{2}, X_{3}, X_{4}, X_{5}$, and $Y$ variable have value score more than 0,6 in each variable. Therefore, the question item of variable are reliable. The results of this study are service quality gives significant influence on outpatients' satisfaction, cost does not give significant influence on outpatients' satisfaction, facility does not give significant influence on outpatients' satisfaction, and customer loyalty gives significant influence on outpatients'satisfaction. The result of this study have contribution in improving the hospital's service quality.
\end{abstract}

\section{PENDAHULUAN}

Perkembangan dunia bisnis saat ini mengalami pertumbuhan yang sangat pesat, baik bisnis yang bergerak di bidang manufaktur maupun jasa. Untuk dapat memperoleh keunggulan dalam persaingan tersebut maka setiap perusahaaan harus mampu memenuhi kepuasan pelanggannya, dengan strategi yang sesuai dengan jasa yang ia tawarkan. Adapun kepuasan pelanggan dapat dipenuhi perusahaan salah satunya melalui pelayanannya. Dengan demikian setiap perusahaan harus mampu memenuhi kepuasan konsumen melalui kualitas pelayanan yang diberikan. 
Sebagai pelayanan kesehatan masyarakat umum, Rumah Sakit memiliki masalah utamayaitu mengenai pelayanan yang diberikan apakah sudah sesuai harapan pasien atau tidak. Oleh karena itu, pihak Rumah Sakit dituntut untuk selalu menjaga kepercayaan pasien dengan meningkatkan kualitas pelayanannya. Azwar (2010) mengatakan bahwa mutu pelayanan kesehatan menunjuk pada tingkat kesempurnaan penampilan pelayanan yang diselenggarakan yang di satu pihak dapat memuaskan para pengguna jasa pelayanan dan di pihak lain tata cara penyelenggaraannya sesuai dengan kode etik profesi serta standar yangtelahditetapkan. Menurut Tjiptono (2008) kualitas layanan adalah ukuranseberapa bagus tingkat layanan yang diberikan mampu sesuai dengan ekspektasi pelanggan. Selain meningkatkan kualitas pelayanan jasa yangdiberikankepada konsumen, Rumah Sakit juga perlu memikirkan tentang harga pelayanannya. Harga yang ditetapkan haruslah tepat atau sesuai di mata konsumen,karena harga yang tidak sesuai atau terlalu mahal malah justru akan membuat konsumen pindahkepelayanan kesehatan lain. Harga adalah jumlah uang yang dibebankan atasproduk/jasa, atau jumlah dari nilai yang ditukar konsume atas manfaat karena memiliki atau menggunakan produk/jasa tersebut (Kotler \& Armstrong, 2008). Menurut Darajat (2010), fasilitas adalah segala sesuatu yang dapat mempermudah upaya dan memperlancar kerja dalam rangka mencapai suatu tujuan. Keberadaan fasilitas seperti kotak saran dan keluhan akan membantu Rumah Sakit dalam memperoleh informasi mengenai hal-hal apa saja yang diinginkan dan menjadi kebutuhan pelanggan.

Kepuasan pelanggan merupakan salah satu unsur yang sangat penting bagi pelanggan dalam mengkonsumsi suatu jasa. Kepuasan konsumen merupakan syarat yang harus di penuhi perusahaan agar mampu sukses menciptakan dan mempertahankan pelanggan. Apabila pelanggan merasa puas, maka dia akan menunjukkan besarnya kemungkinan untuk kembali mengggunakan jasa yang sama. Namun apabila pelanggan tidak merasa puas maka sangat mungkin pasien akan pindah ke penyedia layanan kesehatan lain. Selain itu pelanggan juga mungkin akan menceritakan pengalamannya kepada orang lain yang justru dapat menimbulkan citra buruk di mata pelanggan.

Loyalitas pelanggan sangat menentukan apakah seorang pelanggan akan kembali atau tidak dan apakah mereka akan merekomendasikan Rumah Sakit Medika Permata Hijau kepada orang lain untuk memakainya atau tidak. Untuk mempertahankan loyalitas pelanggan, perlu dilakukan rintangan pengalihan dan strategi menangani keluhan yang baik. Untuk itu perlu diidentifikasi rintangan pengalihan dan strategi penanganan keluhan yang tepat menurut pelanggan agar pasien yang puas bisa menjadi pasien yang loyal bahkan menjadi pasien setia bagi RSMPH.

Rumah Sakit Medika Permata Hijau adalah salah satu Rumah Sakit yang tergabung dalam KPJ Health Care (Bhd) yang mengelola 25 Rumah Sakit yang berpusat di Kuala Lumpur, Malaysia dan 2 Rumah Sakit di Indonesia. RSMPH terletak dilokasi yang sangat strategis dengan akses yang mudah di Jl. Raya Kebayoran Lama No. 64, Jakarta Barat (Dekat ITC Permata Hijau) dengan area tanah seluas 3.500 m2. Rumah Sakit Medika Permata Hijau beroperasi sejak 01. Dengan motto "Care For Life", kami berusaha untuk memberikan pelayanan sebaik-baiknya kepada pasien. Untuk memberikan pelayanan sebaik-baiknya kepada pasien, kami memiliki panduan berupa 5 nilai inti, yaitu: keselamatan, sopan santun, tulus, profesional, dan terus menerus selalu melakukan perbaikan.

Dari beberapa uraian di atas, penelitian ini memiliki beberapa tujuan antara lain: 1) untuk menganalisis pengaruh kualitas pelayanan terhadap kepuasan pasien rawat jalan, 2) untuk menganalisis pengaruh harga terhadap kepuasan pasien rawat jalan, 3) untuk menganalisis pengaruh fasilitas terhadap kepuasan pasien rawat jalan 4) untuk menganalisis pengaruh customer loyalty terhadap kepuasan pasien rawatJalan. 
Jasa merupakan aktivitas, manfaat atau kepuasan yang ditawarkan untuk dijual. Kotler \& Keller (2008) mendefinisikan jasa sebagai setiap tindakan atau kinerja yang ditawarkan oleh satu pihak ke pihak lain yang secara positif tidak berwujud dan tidak menyebabkan perpindahan kepemilikan. Sedangkan Herdiana (2015) yang diartikan jasa adalah Setiap kegiatan atau manfaat yang ditawarkan oleh suatu pihak kepada pihak lain dan pada dasarnya tidak berwujud, serta tidak menghasilkan kepemilikan sesuatu. Menurut Herdiana (2015), jasa memiliki empat karakteristikyaitu: 1) Tidak Berwujud(Intangibility)2) Tidak Dapat Dipisahkan(Inseparability)3) Berubahrubah(Variability)4) Daya Tahan (Perishability)

Menurut Tjiptono (2008), faktor utama yang mempengaruhi kualitas layanan ada dua yaitu expected service dan perceived service. Kualitas pelayanan dapat diwujudkan melalui pemenuhan kebutuhan dan keinginan customer serta ketepatan penyampaian dengan mengimbangi atau melampauai harapancustoemer, Harapan pelanggan dapat dibagimenjadi:1) Will Expectation, adalah tingkat kinerja yang diantisipasi atau diperkirakan konsumen akan diterimanya, berdasarkan informasi yangdiketahuinya. 2) Should Expectation, adalah tingkat kinerja yang sudah sepantasnya diterima oleh konsumen. 3) Ideal Expectation, adalah tingkat konerja optimum atau terbaik yang diharapakan dapat diterimakonsumen

Harga sering dijadikan sebagai indikator kualitas bagi konsumen. Orang sering memilih harga yang lebih tinggi diantara 2 barang karena mereka melihat adanya perbedaan. Apabila harga lebih tinggi, orang cenderung beranggapan bahwa kualitasnya juga lebih baik. Konsumen sering pula menggunakan harga sebagai kriteria utama dalam menentukan nilainya. Barang dengan harga tinggi biasanya dianggap superior dan barang yang mempunyai harga rendah dianggap inferior (rendah tingkatannya) (Swastha, 2007). Keputusan penetapan harga juga penting dalam menentukan seberapa jauh sebuah layanan jasa dinilai oleh konsumen, dan juga dalam proses membangun citra. Penetapan harga juga memberikan persepsi tertentu dalam hal kualitas (Lupiyoadi, 2013)

Menurut Darajat (2010), fasilitas adalah segala sesuatu yang dapat mempermudah upaya dan memperlancar kerja dalam rangka mencapai suatu tujuan. Sedangkan menurut Suryosubroto (2009) fasilitas adalah segala sesuatu yang dapat memudahkan dan memperlancar pelaksanaan suatu usaha, dapat berupa benda-benda maupun uang. Pada sejumlah tipe jasa, persepsi yang terbentuk dari interaksi antar pelanggan dengan fasilitas jasa berpengaruh signifikan terhadap kualitas jasa bersangkutan di mata pelanggan (Tjiptono, 2008). Apabila fasilitas jasa tersedia dengan baik dan memadai maka pelayanan yang diberikan oleh rumah sakit dapat optimal. Pasien juga akan merasa terlayani dengan baik sehingga dengan ketersesiaan fasilitas yang baik dapat menimbulkan kepuasan pasien.

Loyalitas pelanggan merupakan dorongan perilaku untuk melakukan pembelian secara berualangulang dan untuk membangun kestiaan pelanggan terhadap suatu jasa/produk yang dihasilkan oleh suatu perusahaan. Menurut Tjiptono (2008), loyalitas merupakan perilaku pembelian ulang semata-mata menyangkut pembelian merek tertentu yang sama secara berulang kali (bisa dikarenakan memang hanya satu- satunya merek yang tersedia, merek termurah dan sebagainya). Loyalitas menurut Griffin (2010) adalah seorang konsumen dikatakan setia atau loyal apabila konsumen menunjukkan perilaku pembelian secara teratur atau terdapat suatu kondisi dimana mewajibkan konsumen membeli paling sedikit dua kali dalam selang waktu tertentu. Para ahli loyalitas pelanggan menyetujui bahwa loyalitas terbaik didefinisikan sebagai keadaan dalam pikiran, sikap, keyakinan dan keinginan terhadap sutu produk/jasa.

Kotler \& Keller (2008) menyatakan bahwa: "Kepuasan adalah perasaan senang atau kecewa seseorang yang muncul setelah membandingkan kinerja (hasil) produk yang telah dibandingkan dengan alternative yang lain. Berdasarkan definisi tersebut, maka dapat diketahui adanya kesamaan tentang 
komponen kepuasan pelanggan yaitu harapan dan kinerja atau hasil yang dirasakan. Menurut Tjiptono (2008) pada umumnya harapan-harapan pelanggan merupakan perkiraan atau keyakinan pelanggan tentang apa yang diterimanya bila membeli atau mengkonsumsi suatu produk, sedangkan kinerja yang dirasakan adalah persepsi pelanggan terhadap apa yang ia terima setelah mengkonsumsi produk atau jasa yang dibeli. Ada dua faktor yang sangat menentukan kepuasan konsumen yaitu harapan pelanggan dan kinerja yang mereka rasakan. Konsumen akan memiliki harapan mengenai bagaimana produk tersebut seharusnya berfungsi (performance expectation), harapan tersebut adalah standar kualitas yang akan dibandingkan dengan kinerja produk yang sesungguhnya dirasakan.

Semakin banyak rumah sakit yang bersaing di industri kesehatan dan semakin kuat pengaruh pasien, semakin penting peranan pasien dalam membedakan suatu rumah sakit dengan rumah sakit lainnya. Pola pikir pelayanan terhadap pasien harus mencakup semua bagian dari rumah sakit tersebut. Kualitas Pelayanan merupakan tanggung jawab perusahaan/rumah sakit, dan milik semua unit kerja dalam perusahaan. Aplikasi service quality bukan menjadi kewajiban lagi melainkan harus menjadi kebutuhan dasar yang tidak dapat ditawar lagi. Dengan demikian service quality adalah suatukebutuhan bukan suatu pilihan.

Perusahaan harus meningkatkan kualitas pelayanannya pada pelanggan, diman semakin tinggi kualitas pelyanan yang diberikan akan menciptakan kecenderungan perilaku konsumen yang menguntungkan perusahaan. Begitu pula sebaliknya, apabila konsumen tidak mendapatkan pelayanan yang baik dan merasa tidak puas maka akan menimbulkan kecenderungan perilaku konsumen yang tidak menguntungkan sehingga akan merugikan perusahaan (Zeithalm et al., 2009)

\section{Gambar 1. Kerangka Pemikiran}

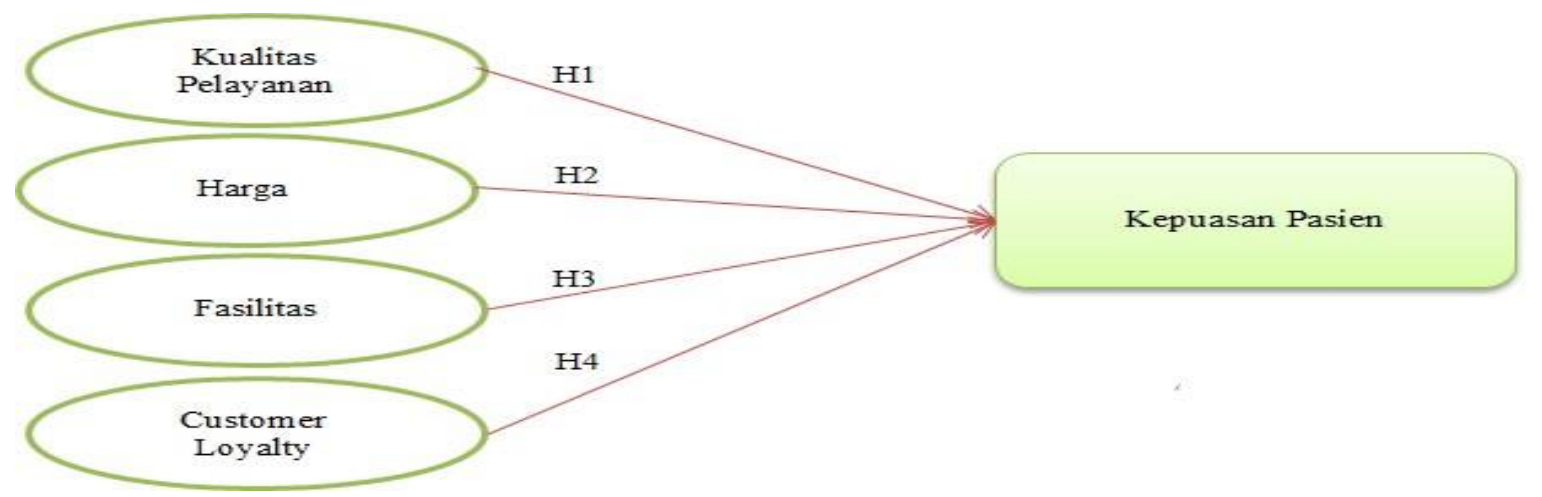

\section{METODE}

Objek penelitian yang dibahas dalam penelitian ini adalah para pasien rawat jalan Rumah Sakit Medika Permata Hijau Jakarta. Penelitian ini menggunakan pendekatan kuantitatif. Metode penelitian kuantitatif yang dijelaskan oleh Sugiyono (2014) adalah: "Metode penelitian sebagai metode yang berlandaskan pada filsafat positivisme; metode yang digunakan untuk meneliti pada populasi atau sampel tertentu;teknik pengambilan sampel biasanya dilakukan dengan perhitungan teknik sampel tertentu yang sesuai;pengumpulan data kuantitatif/statistik dengan tujuan untuk menguji hipotesis yang telah ditetapkan".Data adalah sekumpulan informasi, fakta-fakta atau simbol- simbol yang menerangkan tentang keadaan objek penelitian. Data itu sendiri dibagi menjadi dua yaitu data primer dan data sekunder (Malholtra, 2010) 
Dalam pengambilan sampel, penulis menggunakan metode non probability sampling jenis convenience sampling. Menurut Malholtra (2010), convenience sampling merupakan pengambilan sampel dimana peneliti memilih sampel berdasarkan penilaian terhadap karakteristik anggota sampel secara random, pemilihan responden yang tersedia dan mudah diakses. Metode ini digunakan mengingat keterbatasan sumber daya dan juga karena dalam mengambil data relatif mudah dengan biaya yang relatif murah dengan tingkat reliabilitas dan validitas yang tinggi.

Variabel penelitian dan definisi operasional dalam penelitian ini terdapat dua variabel yaitu variabel dependen dan variabel independen. Menurut Malholtra (2010) variabel independen adalah variabel atau alternatif yang dimanipulasi (yaitu variabel yang diubah-ubah oleh peneliti) dan efeknya diukur serta dibandingkan dalam hal ini yang merupakan variabel independen adalah: 1) Kualitas pelayanan $\left(X_{1}\right) 2$ ) Harga $\left(\mathrm{X}_{2}\right)$ 3) Fasilitas $\left(\mathrm{X}_{3}\right)$ 4) Customer Loyalty $\left(\mathrm{X}_{4}\right)$

Metode analisis data adalah suatu metode yang digunakan untuk mengolah hasil penelitian guna memperoleh suatu kesimpulan. Dalam penelitian ini penulis menggunakan aplikasi SPSS versi 22 for Windows untuk mengolah data profil responden dan Metode analisis yang digunakan dalam penelitian ini adalah regresi berganda, analisis regresi berganda digunakan untuk mengetahui pengaruh variabel independen terhadap variabel dependen atas perubahan dari setiap penurunan atau peningkatan variabel independen yang akan mempengaruhi variabel dependen.

\section{HASIL DAN PEMBAHASAN}

Analisis deskriptif memberikan gambaran tentang data yang diperoleh. Gambaran data ini bisa menjadi acuan untuk melihat karakteristik data yang kita peroleh. Karakteristik data yang disajikan misalnya niali rata-rata, minimum, maksimum, dan standar deviasi. Berikut ini adalah gambaran umum berdasarkan data yang diperoleh.

Tabel 1. Descriptive Statistics

\begin{tabular}{lllllll}
\hline & NStatistic & $\begin{array}{l}\text { Minimum } \\
\text { Statistic }\end{array}$ & $\begin{array}{l}\text { Maximum } \\
\text { Statistic }\end{array}$ & $\begin{array}{l}\text { Sum } \\
\text { Statistic }\end{array}$ & $\begin{array}{l}\text { Mean } \\
\text { Statistic }\end{array}$ & $\begin{array}{l}\text { Std.Deviation } \\
\text { Statistic }\end{array}$ \\
\hline $\begin{array}{l}\text { Kualitas } \\
\text { Pelayanan }\end{array}$ & 100 & 2.37 & 4.79 & 413.74 & 4.1374 & .34349 \\
Harga & 100 & 1.67 & 4.67 & 334.60 & 3.3460 & .49008 \\
Fasilitas & 100 & 1.75 & 4.75 & 405.75 & 4.0575 & .48050 \\
$\begin{array}{l}\text { Customer } \\
\text { Loyalty }\end{array}$ & 100 & 1.40 & 4.80 & 403.40 & 4.0340 & .50136 \\
$\begin{array}{l}\text { Kepuasan } \\
\text { Pasien }\end{array}$ & 100 & 1.20 & 4.80 & 407.00 & 4.0700 & .56880 \\
$\begin{array}{l}\text { Valid N } \\
\text { (listwise) }\end{array}$ & 100 & & & & & \\
\hline
\end{tabular}

Dari tabel di atas dapat diketahui deskripsi statistik tentang skor rata-rata dari variabel-variabel yang digunakan dalam penelitian ini. Untuk variabel kualitas pelayanan jumlah data 100, nilai minimum 2,37, nilai maksimum 4,79, rata-rata 4,1374, dan standar deviasi 0,34349 . Untuk variabel harga jumlah data 100, nilai minimum 1,67 , nilai maksimum 4,67, rata-rata 3,3460, dan standar deviasi 0,49008 .Untuk variabel fasilitas jumlah data 100 , nilai minimum 1,75 , nilai maksimum 4,75 , rata-rata 4,0575 , dan 
standar deviasi 0,48050 .Untuk variabel customer loyalty jumlah data 100 , nilai minimum 1,40, nilai maksimum 4,80, rata-rata 4,0340, dan standar deviasi 0,50136.Untuk variabel kepuasan pasien jumlah data 100 , nilai minimum 1,20, nilai maksimum 4,80, rata-rata 4,0700, dan standar deviasi0,56880.

Uji validitas dalam penelitian digunakan untuk mengukur sah atau valid tidaknya suatu kuesioner. Jadi, semakin tinggi validitas suatu alat ukur, semakin tepat alat ukur tersebut mengenai sasaran. Pengujian validitas dalam penelitian ini adalah dengan mengkorelasikan antara skor butir pertanyaan dengan total skor konstruk atau variabel yang ada. Uji korelasi yang digunakan dengan menggunakan "Pearson Correlation". Dari hasil analisis diketahui satu item (TAN1) nilai korelasi kurang dari $r$ tabel 0,361 (tidak valid). Sedangkan item yang lain nilai $r$ hitung lebih dari $r$ tabel (valid). Dengan ini maka dapat disimpulkan bahwa item kuisioner TAN1 tidak digunakan dalam kuisioner selanjutnya.

Uji reliabilitas berguna untuk menetapkan apakah instrumen yang dalam hal ini kuesioner dapat digunakan lebih dari satu kali, paling tidak oleh responden yang sama akan menghasilkan data yang konsisten. Dengan kata lain, reliabilitas instrumen mencirikan tingkat konsistensi. Pengujian reliabilitas yang digunakan adalah dengan menggunakan metode Cronbach Alpha. Nilai Cronbach's Alpha pada variabel $\mathrm{X}_{1}$ adalah 0,759 dengan nilai lebih besar dari 0,6, sehingga dapat dikatakan item pertanyaan pada variabel tersebut adalah Reliabel.Nilai Cronbach's Alpha pada variabel $\mathrm{X}_{2}$ adalah 0,839 dengan nilai lebih besar dari 0,6, sehingga dapat dikatakan item pertanyaan pada variabel tersebut adalah Reliabel.Nilai Cronbach's Alpha pada variabel $\mathrm{X}_{3}$ adalah 0,827 dengan nilai lebih besar dari 0,6, sehingga dapat dikatakan item pertanyaan pada variabel tersebut adalah Reliabel.Nilai Cronbach's Alpha pada variabel $\mathrm{X}_{4}$ adalah 0,794 dengan nilai lebih besar dari 0,6 , sehingga dapat dikatakan item pertanyaan pada variabel tersebut adalah Reliabel.Nilai Cronbach's Alpha pada variabel Y adalah 0,817 dengan nilai lebih besar dari 0,6, sehingga dapat dikatakan item pertanyaan pada variabel tersebut adalah Reliabel.

Uji normalitas digunakan untuk melihat apakah data yang dipakai dalam penelitian ini terdistribusi secara normal atau tidak. Model yang baik adalah yang memiliki distribusi data normal atau mendekati normal. Untuk mendeteksi normalitas data dapat dilakukan dengan uji K- S. Caranya adalah dengan menentukan terlebih dahulu hipotesis pengujian. Nilai signifikansi (Asym.sig 2 tailed) sebesar 0,055. Karena nilai lebih dari 0,05 , jadi residual terdistribusi normal.

Uji multikolinearitas bertujuan untuk menguji apakah pada model regresi ditemukan adanya korelasi yang tinggi antar variabel independen. Jika terjadi korelasiyang tinggi, maka dinamakan terdapat masalah multikolonieritas. Model regresi yang baik seharusnya tidak terjadi korelasi yang tinggi diantara variabel independen. Multikolinieritas menunjukkan adanya hubungan antara variabel bebas dalam model regresi. Model regresi yang baik tidak menunjukkan adanya gejala multikolinieritas. Pendeteksian ada atau tidaknya multikolinieritas dilakukan dengan melihat nilai VIF. Apabila nilai VIF < 10, maka model regresi bebas dari multikolinieritas. Nilai VIF untuk kualitas pelayanan kurang dari 10 yaitu 2,321, nilai VIF untuk harga juga kurang dari 10 yaitu 1,495, dan juga nilai VIF untuk Fasilitas kurang dari 10 yaitu 2,610 serta nilai VIF untuk Customer Loyalty yaitu 1.778 juga kurang dari 10. Dari nilai VIF seluruh variabel yang ada maka dapat disimpulkan bahwa tidak terjadi gejalamultikolinearitas.

Uji heteroskedastisitas bertujuan untuk menguji apakah dalam sebuah model regresi terjadi ketidaksamaan varians dari residual dari satu pengamatan satu ke pengamatan lain. Jika varians dari residual dari satu pengamatan ke pengamatan yang lain tetap, maka disebut homokedastisitas. Dan jika varians berbeda maka disebut heteroskedastisitas. Model regresi yang baik adalah yang homoskesdatisitas atau tidak terjadi heteroskedastisitas.Dari tabel dapat diketahui bahwa keempat variabel nilai signifikansi lebih dari 0,05 (tidak signifikan). Jadi dapat disimpulkan pada model regresi tidak ada masalah heteroskedastisitas. 
Tabel 2. Hasil Uji Heteroskedastisitas

\begin{tabular}{|c|c|c|c|c|c|}
\hline \multirow{3}{*}{ Model } & \multirow{2}{*}{\multicolumn{2}{|c|}{$\begin{array}{c}\text { Unstandardized } \\
\text { Coefficients }\end{array}$}} & \multirow{3}{*}{$\begin{array}{c}\text { Unstandardized } \\
\text { Coefficients } \\
\text { Beta }\end{array}$} & \multirow{3}{*}{$\mathrm{t}$} & \multirow{3}{*}{ Sig. } \\
\hline & & & & & \\
\hline & B & Std. Error & & & \\
\hline 1 & $-45,765$ & 15,615 & & $-2,931$ & ,004 \\
\hline \multicolumn{6}{|l|}{ (Constant) } \\
\hline KualitasPelayanan & 22,175 & 11,759 & 2,043 & 1,885 & ,063 \\
\hline Harga & $-4,860$ & 5,129 &,- 639 &,- 948 & ,346 \\
\hline Fasilitas & 4,256 & 6,447 & ,549 & 660 & ,511 \\
\hline CustomerLoyalty & 2,270 & 4,486 & ,366 & 660 & ,546 \\
\hline $\mathrm{X}_{1}$ square & $-2,305$ & 1,491 & $-, 1,546$ & $-1,546$ & ,126 \\
\hline $\mathrm{X}_{2}$ square & ,884 & ,736 & ,763 & 1,201 & ,233 \\
\hline $\mathrm{X}_{3}$ square &,- 561 & ,867 &,- 486 &,- 647 & ,519 \\
\hline $\mathrm{X}_{4}$ square &,- 126 & 621 &,- 116 &,- 203 & 840 \\
\hline
\end{tabular}

Analisis regresi linier berganda digunakan untuk mengetahui pengaruh variable independen terhadap variabel dependen baik secara parsial (uji t) maupun secara bersama-sama (uji F). Bentuk umum persamaan regresi linier berganda dengan lima variabel independen yaitu sebagai berikut:

$\mathrm{Y}=\beta_{0}+\beta_{1} \mathrm{X}_{1}+\beta_{2} \mathrm{X}_{2}+\beta_{3} \mathrm{X}_{3}+\beta_{4} \mathrm{X}_{4}+\mathrm{e}$

Koefisien regresi Kualitas Pelayanan sebesar 0.808 bertanda positif menyatakan bahwa variabel Kualitas Pelayanan berbanding lurus dengan tingkat Kepuasan Pasien. Koefisien regresi Harga sebesar 0.156 bertanda positif menyatakan bahwa variabel Harga berbanding lurus dengan tingkat Kepuasan Pasien. Kemudian untuk koefisien regresi Fasilitas sebesar 0,084 bertanda positif menyatakan bahwa variabel Fasilitas berbanding lurus dengan tingkat Kepuasan Pasien. Selanjutnya koefisien regresi Customer Loyalty sebesar 0.320 bertanda positif menyatakan bahwa variabel Customer Loyalty juga berbanding lurus dengan tingkatKepuasan Pasien. Konstanta yang sebesar -1,429 bertanda positif memiliki arti bahwa jika tidak ada Kualitas Pelayanan, Harga, Fasilitas dan Customer Loyalty maka nilai Kepuasan Pasien sebesar -1,429. Selanjutnya, koefisien regresi Kualitas Pelayanan sebesar 0.808 menyatakan bahwa setiap penambahan satu satuan akan meningkatkan kepuasan pasien sebesar 0.808 .

Uji ini digunakan untuk mengetahui apakah dalam model regresi variabel independen secara parsial berpengaruh signifikan terhadap variabel dependen, yaitu untuk mengetahui pengaruh variabel Kualitas Pelayananterhadap Kepuasan Pasien, pengaruh Harga terhadap Kepuasan Pasien, pengaruh Fasilitas terhadap Kepuasan Pasien, dan pengaruh Customer Loyalty terhadap Kepuasan Pasien.

Nilai Sig. untuk variabel Kualitas Pelayanan adalah0.000 $<0.05$, yang berarti variabel Kualitas Pelayananmemiliki pengaruh yang signifikan terhadap Kepuasan Pasien sehingga $\mathrm{H}_{0}$ ditolak. Hasil penelitian ini sejalan hasil penelitian terdahalu yang dilakukan Amin \& Nasharuddin (2013), Mongkaren 
(2013), Nofirza \& Indrayani (2011) yang menyatakan kualitas pelayanan pada berpengaruh kepada kepuasan pasiennya. Masyarakat yang semakin sadar dengan kesehatan terutama daerah perkotaan lebih menuntut rumah sakit memperhatikan tingkat kualitas pelayanannya. Dari hasil analisis data penelitian dapat diinterprestasikan kepuasan pasien akan meningkat seiring dengan peningkatan kualitas pelayanan Rumah Sakit Medika Permata Hijau Jakarta mulai dari aspek fisik (tangible), kehandalan (reliability), ketanggapan (responsiveness), kepastian (assurance) dan empati (emphaty). Kemudian nilai Sig. untuk variabel Harga sebesar $0.058>0,05$, yang berarti variabel Harga tidakmemiliki pengaruh yang signifikan terhadap Kepuasan Pasien sehingga $\mathrm{H}_{0}$ diterima.

Hasil penelitian ini berbeda dengan penelitian sebelumnya yang dilakukan oleh Malik et al. (2012) yang menyatakan harga berpengaruh terhadap kepuasan pelanggan tetapi merujuk penelitian yang dilakukan oleh Mahmud et al. (2013) penelitian ini sejalan yang menyatakan bahwa harga tidak berpengaruh terhadap kepuasan pelanggan

Selanjutnya nilai Sig untuk variabel Fasilitas $0.447>0.05$, yang berarti variabel Fasilitas tidak memiliki pengaruh yang signifikan terhadap Kepuasan pasien sehingga $\mathrm{H}_{0}$ diterima. Hasil penelitian ini sejalan dengan penelitian yang dilakukan oleh Rizal et al. (2017)dan Dewi (2017) yang menyatakan bahwa loyalitas pasien berpengaruh signifikan terhadap kepuasan pasien. Dengan menggunakan skala yang sama untuk setiap pertanyaan yang diajukan maka dapat dilihat variabel mana yang lebih dominan dengan menggunakan standardized coefficients beta pada tabel. Dari tabel tersebut dapat dilihat bahwa nilai standardized coefficients beta untuk variabel Kualitas Pelayananlebih besar dibandingkan dengan variabel Customer Loyalty yaitu sebesar 0,808. Hal ini berarti variabel Kualitas Pelayananmerupakan variabel yang lebih dominan dibandingkan dengan variabel Customer Loyaltydalam mempengaruhi kepuasan pasien sebagai variabel dependen.

Uji F digunakan untuk mengetahui apakah variabel independen secara simultan berpengaruh terhadap variabel dependen atau tidak. Nilai signifikan adalah 0,000 yang bernilai kurang dari $\alpha=0.05$, oleh karena itu keputusan adalah Tolak $\mathrm{H}_{0}$. Sehingga dapat disimpulkan bahwa Kualitas Pelayanan, Harga, Fasilitas, dan Customer Loyalty secara bersama-sama memiliki pengaruh terhadap kepuasan pasien.

Analisis koefisien deteminasi (R2) digunakan untuk menguji sejauh mana variasi variabel independen mampu menjelaskan variabel dependen. Nilai yang digunakan adalah Adjusted R Square sebagai koefisien determinasi adalah hasil perhitungan R2, dapat dilihat dari tabeldiatas bahwa adjusted R2 sebesar 0,675. Hal ini berarti variabel independen yaitu Kualitas Pelayanan, Harga, Fasilitas dan Customer Loyalty memiliki pengaruh sebesar 67,50 \% terhadap Kepuasan Pasien,sisanya sebesar 32,5 \% dipengaruhi oleh faktor lain yang tidak diteliti dalam penelitian ini.

\section{PENUTUP}

\section{Kesimpulan}

Bahwa kualitas pelayanan berpengaruh signifikan terhadap kepuasan pasien rawat jalan Rumah Sakit Medika Permata Hijau Jakarta dan merupakan faktor yang paling dominan yang mempengaruhi kepuasan pasien rawat jalan Rumah Sakit Medika Permata HijauJakarta.Bahwa harga tidak berpengaruh signifikan terhadap kepuasan pasien rawat jalan Rumah Sakit Medika Permata Hijau Jakarta, hal ini menunjukkan keterjangkauan harga tidak dapat meningkatkan kepuasan pasien. Tidak signifikannya penagaruh harga terhadap kepuasan pasien dapat disebabkan oleh dua faktor yaitu: pertama, pemilihan rumah sakit lebih dipengaruhi oleh faktor akses dan ketersediaan layanan/kamar. Kedua, semakin 
banyaknya rumah sakit baik milik pemerintah maupun swasta terutama di kota besar seperti Kota DKII Jakarta yang harganya relatif tidak jauhberbeda.

Bahwa fasilitas tidak berpengaruh signifikan terhadap kepuasan pasien rawat jalan Rumah Sakit Medika Permata Hijau Jakarta. Hal ini seperti yang dijelaskan sebelumnya bahwa kepuasan merupakan fungsi dari harapan, kinerja penyedia jasa dan fasilitas diberikan untuk memenuhi harapan pelanggan/pasien.Bahwa customer loyalty berpengaruh signifikan terhadap kepuasan pasien rawat jalan rumah sakit medika permata hijau Jakarta, menunjukkan bahwa rumah sakit medika permata hijau Jakarta perlu memperkuat aspek-aspek yang merefleksikan kepuasan pasien. Rumah sakit Medika Permata Hijau Jakarta perlu secara aktif dan berkesinambungan meminta masukan pasien mengenai kepuasan terhadap pelayanan yang diberikan.Kegiatan survei kepuasan pelanggan dapat dilakukan secara berkalaagar Rumah Sakit Medika Permata Hijau Jakarta peka terhadap hal-hal yang dapat menurunkan dan meningkatkan kepuasan pasien sehingga dapat segera menindaklanjutinya dalam rangka mempertahankan dan meningkatkan loyalitas pasien.

\section{Saran}

Penelitian ini tentu saja jauh dari kata sempurna dan memiliki berbagai keterbatasan sehingga masih memerlukan penyempurnaan untuk penelitian di masa yang akan datang. Oleh karena itu, berikut ini beberapa saran yang memungkinkan untuk dapat diberikan kepada perusahaan dan penelitian selanjutnya, antara lain: rumah Sakit Medika Permata Hijau harus lebih meningkatkan kualitas pelayanannya baik dilihat dari segi tangible, reliability, responsiveness, assurance maupun emphaty kepadapasien.Perlu dilakukan riset terhadap pasien mengenai harga yang ditetapkan apakah sudah sesuai dengan harapan konsumen terhadap kualitas pelayanan yang diterima. Serta melakukan survei perbandingan harga dengan rumah sakit lainnya.Variabel fasilitas berpengaruh signifikan terhadap kepuasan pasien, namun perlu dilakukan peningkatan fasilitas oleh pihak rumah sakit sehingga fasilitas yang diberikan kepada pasien akan menjadi lebih baik dan berpengaruh tergadap kepuasan pasien.Penelitian ini dapat dikembangkan lebih lanjut dengan menambah variabel penelitian lainnya misalnya variabel citra perusahaan karena selain dari sisi perusahaan/rumah sakit makin bagus citra yang dimiliki suatu perusahaan maka semakin tinggi pula loyalitas pasien terhadap perusahaan/rumah sakit tersebut dan memberikan kepuasan terhadap pasien dengan begitu nantinya diharapakan penelitian ini akan mengukur dan menilai segala aspek yang berhubungan dan terkait sehingga diharapkan hasil penelitian yang lebih mendalam dan bermanfaat.

\section{DAFTAR PUSTAKA}

Amin, M., \& Nasharuddin, S. Z. (2013). Hospital service qualityand its effect on patient satisfaction and behavioural intention. CGIJ, 18(3), 238-254. https://doi.org/10.1108/CGIJ-05-20100016

Azwar, A. (2010). Menjaga Mutu Pelayanan Kesehatan Aplikasi Prinsip Lingkaran Pemecahan Masalah. Jakarta: Pustaka Sinar Harapan.

Darajat, Z. (2010). Kesehatan Mental. Jakarta: CV. Haji Masagung.

Dewi, R. (2017). Pengaruh Kualitas Pelayanan Terhadap Loyalitas Pasien Pengguna Bpjs Dengan Kepuasan Pasien Sebagai Variabel Intervening. Jurnal Manajemen Dayasaing, 18(2), 146. https://doi.org/10.23917/dayasaing.v18i2.4511 
Griffin, J. (2010). Customer Loyalty How to Earn it, How to Keep It. Kentucky (US): Mc Graw Hill.

Herdiana, N. (2015). Manajemen Strategi Pemasaran. Bandung: Pustaka Setia.

Kotler, \& Armstrong. (2008). Principles of Marketing. Prentice Hall Person Education.

Kotler, P., \& Keller, K. L. (2008). Marketing Management (12th ed.). New York: Prentice Hall.

Lupiyoadi, R. (2013). Manajemen Pemasaran Jasa Berbasis Kompetensi (3rd ed.). Jakarta: Salemba Empat.

Mahmud, A., Jusoff, K., \& Hadijah, S. T. (2013). The effect of service quality and price on satisfaction and Loyalty of Customer of commercial flight service industry. World Applied Sciences Journal, 23(3), 354-359. https://doi.org/10.5829/idosi.wasj.2013.23.03.13052

Malholtra, N. K. (2010). Marketing Research an Applied Orientation. New Jersey: Pearson.

Malik, M. E., Ghafoor, M. M., \& Iqbal, H. . (2012). Impact of Brand Image, Service Quality and Price on Customer Satisfaction in Pakistan Telecommunication sector. IJBSS, 3(23), 106-110. Retrieved from http;//www.ijbssnet.com/journals/vol.3 no.23

Mongkaren, S. (2013). Fasilitas dan Kualitas Pelayanan Pengaruhnya Terhadap Kepuasan Pengguna Jasa Rumah Sakit Advent Manado. Jurnal EMBA (Internet), 1(4), 493-503. Retrieved from http://ejournal.unsrat.ac.id/index.php/emba/article/viewFile/2723/2276

Nofirza, K., \& Indrayani. (2011). Aplikasi Metode Kano dalam Analisis Indikator Kualitas Pelayanan di Rumah Sakit Arifin Ahmad Pekanbaru. Jurnal Sains, Teknologi Dan Industri, 9(1), 1-8.

Rizal, R., Suardi, M., \& Yulihasri, Y. (2017). Pengaruh Kualitas Pelayanan dan Kepuasan Pasien Peserta BPJS Kesehatan sebagai Mediasi terhadap Loyalitas Pasien. Jurnal Sains Farmasi \& Klinis, 3(2), 108. https://doi.org/10.29208/jsfk.2017.3.2.112

Sugiyono. (2014). Metode Penelitian Kuantitatif, Kualitatif Dan $R \&$ \& . Bandung: Alfabeta.

Suryosubroto. (2009). Proses Belajar Mengajar Di Sekolah. Jakarta: Rineka Cipta.

Swastha, B. (2007). Manajemen Pemasaran Modern. Yogyakarta: Liberty Offset.

Tjiptono, F. (2008). Strategi Pemasaran (3rd ed.). Yogyakarta: Andi.

Zeithalm, V., Bitner, M. J., \& Gremler, D. (2009). Services Marketing. New York: McGraw-Hill. 